\title{
Perbandingan Jarak Loncatan pada Beberapa Spesies Belalang (Orthoptera)
}

\author{
Ari Sugiarto \\ Email: sugiartoari13@gmail.com
}

\begin{abstract}
Abstrak
Belalang memiliki kemampuan meloncat untuk berpindah dari satu tempat ke tempat lainya. Selain itu, belalang menggunakan kemampuan meloncatnya untuk melarikan diri dari pemangsa. Jarak loncatan beberapa spesies belalang diperkirakan tidak sama, hal ini memunculkan gagasan untuk melakukan penelitian untuk mengukur jarak loncatan beberapa spesies belalang. Penelitian ini dilakukan di dalam ruangan tertutup dengan ukuran $5 \mathrm{~m} \times 5 \mathrm{~m}$. Spesies belalang yang diukur jarak loncatannya yaitu Atractomorpha crenulata, Gesonula mundata, Oxya hyla, dan Xenocatantops humilis. Pemilihan ke empat spesies belalang ini diperkirakan memiliki jarak loncatan yang berbeda. Hasil penelitian menunjukkan bahwa Oxya hyla memiliki jarak loncatan yang paling jauh dibanding Atractomorpha crenulata, Gesonula mundata, dan Xenocatantops humilis. Atractomorpha crenulata memiliki jarak loncatan yang paling pendek dibading Oxya hyla, Gesonula mundata, dan Xenocatantops humilis. Perbedaan jarak loncatan ini dapat menggambarkan bahwa, Oxya hyla dan Gesonula mundata lebih susah untuk ditangkap dibandingkan Atractomorpha crenulata dan Xenocatantops humili.
\end{abstract}

Kata kunci: Belalang, Jarak loncatan

\section{Pendahuluan}

Belalang merupakan serangga yang termasuk ke dalam ordo Orthoptera. Belalang mudah ditemukan pada vegetasi rerumputan dan semak seperti pada ekosistem persawahaan. Belang memiliki kemampuan meloncat untuk berpindah dari satu tempat ke tempat lainnya selain menggunakan sayap. Selain itu, belalang menggunakan kemampuan meloncatnya untuk menghindari pemangsa. Menurut Hawlena et al. (2011), kecepatan loncatan dan jarak loncatan belalang akan bertambah dengan adanya ancaman dari pemangsa. Menurut Burrows dan Picker (2010), kekuatan loncatan akan lebih besar dengan menggunakan kedua kaki belakang dibandingkan dengan menggunakan satu kaki belakang.

Kekuatan loncatan dan jarak loncatan beberapa spesies belalang diperkirakan tidak sama. Hal ini yang melandasi gagasan dilakukan penelitian ini untuk mengetahui jarak loncatan beberapa spesies belalang. Manfaat dari penelitian ini juga dapat

membedakan keagresifan beberapa spesies belalang dengan melihat perbandingan jarak loncatannya.

\section{Metode Penelitian}

Penelitian ini dilakukan pada bulan Desember 2018. Penelitian ini dilakukan pada ruangan tertutup dengan lebar $5 \times 5 \mathrm{~m}$. Penggunaan ruangan berukuran $5 \times 5 \mathrm{~m}$ ini dengan mempertimbangkan perkiran jarak loncatan belalang yang diukur tidak melebihi $5 \mathrm{~m}$. Menurut Hawlena et al. (2011), belang terlebih dahulu harus diaklimatisasi selama 30 menit pada ruangan yang akan digunakan untuk mengukur jarak loncatan. Seletelah diaklimatisasi diukur panjang tubuh belalang yang akan diukur jarak loncatnnya. Pengukuran jarak loncatan belalang dilakukan dengan mengukur posisi awal belalang sampai ke posisi belalang setelah meloncat. Jarak loncatan yang diukur adalah jarak loncatan yang tanpa diikuti oleh kepakan sayap. Diukur 
juga intesitas cahaya, suhu udara, dan kelembaban udara dalam ruangan.

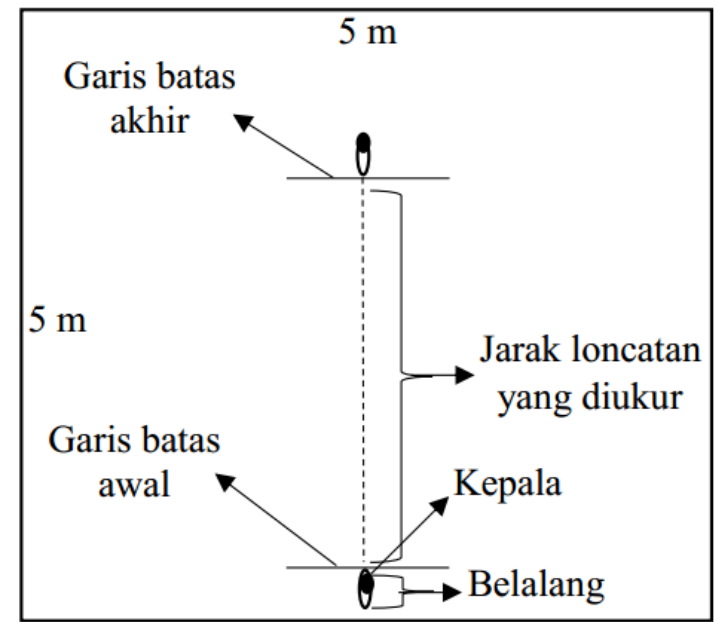

Gambar 1. Skema pengukuran jarak loncatan belalang

Spesies belalang yang diukur jarak loncatannya yaitu Atractomorpha crenulata, Gesonula mundata, Oxya hyla, dan Xenocatantops humilis. Menurut Sugiarto (2018), Atractomorpha crenulata, Gesonula mundata, Oxya hyla, dan Xenocatantops humilis merupakan spesiesspesies belalang yang mudah untuk ditemukan. Selain itu pertimbangan dalam memilih ke 4 spesies belalang ini yaitu diperkirakan jarak loncatan masing-masing spesies berbeda-beda. Spesies belalang yang akan diukur jarak loncatannya ini ditangkap dengan menggunakan insect net pada ekosistem persawahan. Belalang yang tertangkap dimasukkan kedalam toples. Pengkuran jarak loncatan pada masingmasing spesies belalang dilakukan dengan 5 kali pengulangan, setiap pengulangan menggunakan individu yang berbeda. Data yang diperoleh dirata-ratakan dan dicari standar deviasinya

\section{Hasil dan Pembahasan}

Berdasarkan penelitian yang telah dilakukan, dipatkan hasil yaitu:

Tabel 1. Rata-rata jarak loncatan pada beberapa spesies belalang (Orthoptera)

\begin{tabular}{ll}
\hline Spesies & Rata-rata jarak loncatan $(\mathbf{c m})$ \\
\hline Atractomorpha crenulata & $55,8 \pm 8,367$ \\
Gesonula mundata & $102,6 \pm 18,721$ \\
Oxya hyla & $107 \pm 12,260$ \\
Xenocatantops humilis & $68 \pm 13,590$ \\
\hline
\end{tabular}

Rata-rata jarak loncatan Oxya Hyla paling jauh dibading dengan spesies belalang lainnya dengan rata-rata jarak loncatan sejauh $107 \mathrm{~cm}$, sedangkan ratarata jarak loncatan Atractomorpha crenulata paling pendek dibanding jarak loncatan belalang lainnya dengan rata-rata jarak loncatan sejauh $55,8 \mathrm{~cm}$. Rata-rata jarak loncatan Gesonula mundata tidak berbedah jauh dari Oxya hyla yaitu sejauh $102,6 \mathrm{~cm}$. Perbedaan jarak loncatan ini juga diperkirakan menyebabkan perbedaan keberadaan belalang pada suatu ekosistem. Menurut Sugiarto (2018), terdapat perbedaan keberadaan beberapa spesies belalang pada ekosistem persawahan sebelum dan sesudah tergenang air. Pada saat tergenang air, vegetasi pada kawasan persawahan cenderung tumbuh berkelompok, karena beberapa vegetasi tenggelam oleh genangan air. Kemanpuan jarak loncatan Gesonula mundata dan Oxya hyla yang lebih jauh dibanding Atractomorpha crenulata dan Xenocatantops humilis yang diperkirakan menyebabkan Gesonula mundata dan Oxya hyla cendrung berada di tengah persawahan dan Atractomorpha crenulata dan Xenocatantops humilis cenderung berada di dekat tepian persawahan.

Panjang rata-rata belalang yang dipakai pada penelitian yaitu Atractomorpha 
crenulata 3,32 cm, Gesonula mundata 3,3 $\mathrm{cm}$, Oxya hyla 2,54 cm, dan Xenocatantops humilis 2,46 cm. Dapat diperkirakan Gesonula mundata dan Oxya hyla lebih agresif dibading Atractomorpha crenulata dan Xenocatantops humilis. Hal ini membuat Gesonula mundata dan Oxya hyla lebih susah ditangkap dibanding Atractomorpha crenulata dan Xenocatantops humilis. Menurut Queathem dan Full (1995), perbedaan variasi jarak loncatan belalang juga terlihat pada fase instar. Jarak loncatan pada fase ini dipengaruhi oleh fakto pertambahan massa tubuh dan produksi gaya.

Intensitas cahaya pada ruangan yang dipakai untuk mengukur jarak loncatan belalang yaitu rata-rata 143 lux, rata-rata suhu udara $29,7{ }^{\circ} \mathrm{C}$, dan rata-rata kelembaban udara $89 \%$. Menurut Almeida dan Camara (2008) selain faktor fisik, tipe vegetasi pada suatu ekosistem mempengaruhi keberadaan belalang.

\section{Kesimpulan}

Pengukuran jarak loncatan beberapa spesies belalang menunjukkan adanya perbedaan jarak loncatan. Oxya hyla memiliki jarak loncatan yang paling jauh dibanding Atractomorpha crenulata, Gesonula mundata, dan Xenocatantops humilis. Atractomorpha crenulata memiliki jarak loncatan yang paling pendek dibanding Oxya hyla, Gesonula mundata, dan Xenocatantops humilis. Perbedaan jarak loncatan dari beberapa spesies belalang ini dapat menggambarkan keagrasifannya. Oxya hyla dan Gesonula mundata diperkirakan lebih agresif dibandingkan Atractomorpha crenulata dan Xenocatantops humili. Ini juga dapat menggambarkan bahwa Oxya hyla dan Gesonula mundata lebih susah untuk ditangkap dibandingkan Atractomorpha crenulata dan Xenocatantops humili.

\section{Daftar Pustaka}

Almeida, A.V dan Camara, C.A.G. 2008. Distribution of Grasshoppers (Othoptera: Acridoidea) in The Tapacurá Ecological Station (São Lourenço da Mata, PE / Brazil). J. Biol. 68: 21-24.

Burrows, M dan M.D. Picker. 2010. Jumping Mechanisms and Performance of Pygmy Mole Crickets (Orthoptera, Tridactylidae). Journal of Experimental Biology. 213. 2386-2398.

Hawlena, D., Holger, K., Eric, R.D., dan Oswald, J.S. 2011. Grasshoppers Alter Jumping Biomechanics to Enhance Escape Performance Under Chronic Risk of Spider Predation. Functional Ecology. 25. 279-288.

Queathem, E.J dan R.J. Full. 1995. Variation in Jump Force Production within an Instar of the Grasshopper Schistocerca americana. J. Zool. 231: 605620.

Sugiarto, A. 2018. An Inventory of Grasshoppers (Orthoptera: Acrididae) in the Plantation and Rice Field Ecosystems of Serdang Menang Village, Sirah Pulau Padang Sub-district, Ogan Komering Ilir District. https://doi.org/10.31227/osf.io/h fxp9

Sugiarto, A. 2018. Impact of Standing Water on the Existence of Several Species of Grasshoppers (Orthoptera) in the Rice Field Ecosystem. https://doi.org/10.31220/osf.io/a kbgz. 